\title{
The late ascent of Darwin's Descent: exploring human evolution and women's role for a new China, 1927-1965
}

\author{
Lijing Jiang* \\ STS Program, Colby College \\ *Corresponding author: Lijing Jiang, Email: Jiang.Lijing@gmail.com
}

\begin{abstract}
Darwin's ideas held sway among Chinese intellectuals by the early twentieth century. Yet the usual emphasis was a Spencerism instead of Darwin's original ideas. As a result, translations of The Descent of Man in the early twentieth century quickly fell into oblivion. When the embryologist Zhu Xi (1900-62) eventually decided to give all evolutionary theories a comprehensive examination, he nevertheless found the idea of sexual evolution inadequate, as expressed in his volume Biological Evolution (1958). Only in the 1950s did serious efforts to translate Descent gather momentum, thanks to eugenicist and sociologist Pan Guangdan (1899-1967). Such efforts were not only responses to a renewed interest in Darwinism under the socialist regime, but also expressions that synthesized both scholars' earlier paths in wrestling with schemes of human evolution and the roles of women in China's survival and renewal. Trained in different scientific and cultural milieus and holding almost oppositional views, the two scholars nevertheless converged in finding new meanings in Darwin's Descent.
\end{abstract}

Topics of race and gender loomed large in a number of cultural debates in early twentieth-century China. A number of scientists, translators, and writers were preoccupied not only with the status of the Chinese nation in the world's racial scale and with the nation's future, but also with the question of how human sex and gender should be defined through a proper assimilation of modern medical and biological sciences. ${ }^{1}$ In the first three decades of the century, when certain European thinkers regarded the nation as corresponding to a biologically homogeneous unit, the idea emerged and took hold that the Chinese nation had been formed by descendants of a single ancestor, the Yellow Emperor. ${ }^{2}$ Simultaneously, sex and gender started to be defined in biological terms, leading to the naturalization of gender differences based on anatomical and physiological difference. In order to translate the assigned biological characteristics of sex and gender without alluding to Chinese medical canons or old cultural understandings, the term xing (originally a Chinese character for human nature) was adapted to

1 Howard Chiang, After Eunuchs: Science, Medicine, and the Transformation of Sex in Modern China, New York: Columbia University Press, 2018.

2 Frank Dikötter (ed.), The Construction of Racial Identities in China and Japan: Historical and Contemporary Perspectives, Honolulu: University of Hawaii Press, 1997, pp. 3, 12.

(c) The Author(s), 2021. Published by Cambridge University Press on behalf of British Society for the History of Science. This is an Open Access article, distributed under the terms of the Creative Commons Attribution licence (http://creativecommons.org/ licenses/by/4.0/), which permits unrestricted re-use, distribution, and reproduction in any medium, provided the original work is properly cited. 
denote sex itself, linguistically highlighting gender as deterministic of individual attributes. ${ }^{3}$

Given this fascination with race and sex, it may seem odd that translations of Charles Darwin's The Descent of Man, and Selection in Relation to Sex, or a deeper engagement with it, fell into relative oblivion for both scientists and other Chinese intellectuals. Before the mid-century, there were two translations of Descent. One was a full-length translation of the 1874 edition, published in 1930, by the translator Ma Junwu (1881-1940), who had previously published a full translation of Darwin's On the Origin of Species. The other translation was a self-printed book published in 1934, based on an abridged version edited by Vance Randolph, The Substance of the Descent of Man (1926). ${ }^{4}$

New efforts to produce updated translations emerged only in the 1950s. The major translator, Pan Guangdan, had obtained degrees in genetics and eugenics from Columbia University and Cold Spring Harbor Laboratory, before meandering through a series of original projects examining and criticizing Chinese customs and sexual practices with eugenic genealogical studies. Another biologist who commented on sexual selection with critical eyes was $\mathrm{Zhu} \mathrm{Xi,} \mathrm{who} \mathrm{had} \mathrm{studied} \mathrm{at} \mathrm{the} \mathrm{University} \mathrm{of} \mathrm{Montpellier} \mathrm{for} \mathrm{his}$ doctoral degree in biology, while being heavily influenced by neo-Lamarckian ideas. He published a series of works popularizing science throughout the 1930s and 1940s that advocated women's active role in society and the reform of the Chinese marriage system in light of recent research in evolutionary and reproductive biology. While Pan had migrated from biological science to studies of the social in seeking a eugenic future for China, Zhu remained focused on the developmental process of individual organisms and how social factors might affect such individuals' biological functioning. Their different understandings of heredity in humans and women's role in China's futures led them to disparate evaluations of Darwin's Descent in later years, especially regarding the concept of sexual selection. It is nevertheless interesting that the two scholars both revisited Darwin's text in the 1950s, when both scientists' social visions became precariously dangerous to discuss under the socialist regime, as indeed was the case with the tenets of modern genetics.

For Pan, translating Descent was a reassuring experience. Darwin's emphasis on the important role of sexual selection in the evolution of beauty, temperament, social morality and rituals resonated with Pan's views about the formation and social roles of sexual practices. Indeed, in a reminiscence, his long-term friend Fei Xiaotong mentioned how Pan had caressed the original copy of Descent (1874), which was hard to find within China and had been newly imported for Pan to translate. ${ }^{5}$ For Zhu, however, Darwin's explanations of how different human societies and conventions took shape were based on an incorrect premise of competition, Malthusian or sexual in nature. To correct this premise, he believed more emphasis should be put on individual development in one generation instead of biological heredity. Both Pan's and Zhu's views found expressions in the Republican period and became repressed under the socialist regime. In socialist China, the animal origins of the human were widely acknowledged, and human evolution was fashioned as a Marxist process in which 'labour formed humanity'. Although Pan's and Zhu's ideas were almost antithetical to each other, Darwin's text offered them a refuge in which to dwell in the biological principles beneath their social visions. ${ }^{6}$ Overall, the disparate

3 Leon Antonio Rocha, 'Xing: the discourse of sex and human nature in modern China', Gender \& History (2010) 22(3), pp. 603-28; Chiang, op. cit. (1).

4 Charles Darwin and Vance Randolph, Renlei youlai (tr. Renwen Shu), Shanghai: Renwen Yinshuguan, 1934.

5 Charles Darwin, Renlei de youlai (The Descent of Man) (tr. Pan Guangdan and Hu Shouwen), Shanghai: Commercial Press, 1983, p. 948.

6 Sigrid Schmalzer, The People's Peking Man: Popular Science and Human Identity in Twentieth-Century China, Chicago: The University of Chicago Press, 2008. 
views demonstrate two parallel understandings of race and gender in China in the first half of the twentieth century. At the centre of the issue was how women's role should be conceived for China's future - to continue the traditional mode of marriage and childbearing based on matching family status, or, equipped with biological knowledge, to radically participate in a more egalitarian society. Pan's answer was about establishing a regulated, and particularly Confucian, eugenic state, and Zhu was more concerned with the cultivation of an anarchist society based on mutual love and women's education.

This paper, by delineating the intellectual paths of Pan and Zhu, leading to their respective assessment of Descent in the 1950s, suggests that the Darwinian concept of sexual selection was of interest in part because of its potential for improving the Chinese nation via gender relations. This is indicated by both scholars' demonstrably intense interest in the biology of sex and its social function early in their careers. Under the mantel of Darwin, different social imaginations about women's roles continued their expressions in implicit ways in the period of high socialism. The discussion of sexual selection in the 1950s, while seeming to be purely biological, concealed subtle political articulations.

Overall, within China, the concept of sexual selection was less influential and more controversial than the idea of natural selection or human evolution. Too broad a depiction of the global reception of Darwinism, even confined within national boundaries, may overlook the introduction of separate individual concepts, which might be equally culturally significant. Regarding Darwinism in modern China, scholars have covered extensive ground in the last half-century. Benjamin Schwartz's now classic study of Yan Fu, the translator who first brought many of Darwin's ideas to a Chinese readership, established the importance of the idea of evolution as a potential guide to the urgent question of ways to ensure the nation's survival. ${ }^{7}$ James Pusey's study of late Qing revolutionaries and their views about evolution expanded the scope of Darwin's influence in concrete reforms and revolutions in the late nineteenth and early twentieth centuries. ${ }^{8}$ In recent years, there have also been illuminating works interpreting how Darwin became reflected in museum practice and in popular writings about evolution, especially human evolution. ${ }^{9}$ Two recent and refreshing articles by Xiaoxing Jin, furthermore, examine the interpretation of the concept of transmutation in Ma Junwu's translation of On the Origin of Species and the multiple processes that integrated the idea of evolution into China's cultural landscapes. ${ }^{10}$ Yet, among the expanding scholarship, studies of how Darwinian concepts played into individual scientists' own intellectual agendas remain rare. This essay shows that beyond the general writing about Darwin by social reformers and popular-science writers, concepts such as sexual selection might be explored fully only in the socialist context.

\section{The neglect of Descent amongst Darwin's Chinese converts, I898-1934}

The lukewarm reception of translations of Descent in the 1930s was partially due to the proliferation of all kinds of science translations and popularizations at the time that competed for attention and eclipsed one another's relative significance. Nevertheless, in aggregate these market competitors conveyed an image of the power of modern science

\footnotetext{
7 Benjamin Schwartz, In Search of Wealth and Power: Yen Fu and the West, Cambridge, MA: Harvard University Press, 1964.

8 James Reeve Pusey, China and Charles Darwin, Cambridge, MA: Harvard University Asia Center, 1983.

9 Schmalzer, op. cit. (6). Haiyan Yang, 'Knowledge across borders: the early communication of evolution in China', in Bernard Lightman, Gordon McOuat and Larry Stewart (eds.), The Circulation of Knowledge between Britain, India and China: The Early-Modern World to the Twentieth Century, Leiden: Brill, 2013, pp. 182-208.

10 Xiaoxing Jin, 'Translation and transmutation: the Origin of Species in China', BJHS (2019) 52(1), pp. 117-41; Jin, 'The evolution of evolutionism in China, 1870-1930', Isis (2020) 111(1), pp. 46-66.
} 
and cultivated a popular 'scientism' within the young republic. In addition, by the 1930s, the primate origin of humans was no longer a novel idea for educated readers. The influential commentary and translation of Thomas Henry Huxley's Evolution and Ethics made by the eminent scholar Yan Fu (1854-1921) almost four decades earlier had firmly established Darwin's argument about humanity's animal origin in the minds and psyches of the younger generation. Yan, like many science translators and writers after him, associated the importance of understanding Darwinian evolution with understanding the current crisis and the future fate of the Chinese nation. Through Yan's work the perceived crisis of the Chinese race catalysed a social Darwinist interpretation of evolutionary theories.

Published near the end of the previous century, Yan's translation of Huxley was the most frequently consulted text about Darwin in China, even after the publication of Ma's translation of Origin. As a scholar deeply concerned about the fate of China at a time when the country was encountering the Western world, Yan carefully curated texts, focusing on those that he thought able to reveal scientific methods for analysing human societies. His corpus would eventually include Adam Smith's The Wealth of Nations and John Stuart Mill's A System of Logic. Among these, Huxley's Evolution and Ethics had been his first monograph undertaken for translation. The project's duration overlapped with the years following China's defeat in the First Sino-Japanese War in 1895. With the unexpected defeat, the deeply felt humiliation motivated Yan to advocate ideas and values that he believed would help transform Chinese society and 'preserve the nation' with modern scientific thinking. Yan chose Huxley's book over Darwin's Origin or Descent because he intended to make evolution distinctly applicable to developing the Chinese nation in racial competition, and perhaps also due to his general unfamiliarity with biology. ${ }^{11}$

With a clear intention of intervening in cultural questions of the day, Yan's translation was interlaced with profuse commentaries in which he often argued against Huxley's various points. These additional commentaries facilitated Yan's interventions, even distortions, of the text, as he disagreed with Huxley's conception about the proper course of human evolution. Yan found more amenable the views of Herbert Spencer (1820-1903), who had argued against 'human meddling' with natural selection's ability to eliminate human populations. Yet Yan found Spencer's writings overly diffusive for a manageable translation project. ${ }^{12}$ Huxley's lectures, in contrast, were succinct. They dealt directly with topics relevant to Yan's concerns with 'self-strengthening and preservation of the race'. ${ }^{13}$ Although Huxley's lectures constituted an attack on the social Darwinism that Spencer advocated, they nevertheless gave Yan an opportunity to debate the issue. While Huxley fully supported Darwin's ideas on biological evolution, in these lectures he attempted to protect human ethics from the encroachment of the notion of the 'survival of the fittest'. For Huxley, Spencer's suggestion that governments should apply evolutionary principles to human society without humanitarian concerns for 'the weak' appeared brutal and crass. ${ }^{14}$ In his commentaries, Yan correlated Spencer's concept of 'the Unknowable' to the principles functioning between the heaven and the earth suggested in Taoism, Buddhism and even Confucian traditions. The amoral natural force behind biological evolution, human and non-human alike, for Yan, was equivalent to the highest principles of nature (heaven and earth) depicted in these religious and philosophical traditions that went beyond the dichotomy of benevolence and non-benevolence.

11 Schwartz, op. cit. (7), especially Chapter 4, pp. 91-112.

12 Schwartz, op. cit. (7), p. 98.

13 Thomas Henry Huxley, Tianyan Lun (tr. Yan Fu), Beijing: China Youth Press, 2009, p. 4.

14 Schwartz, op. cit. (7), p. 102. 
Yan pointed out that these amoral forces had rationalities that went beyond what human minds could grasp, and indeed should not be meddled with. For Yan, to grasp evolution was to reveal the reality of the world previously hidden from the chinese before the translation of Darwin. In other words, he considered social Darwinism the key to guide the future development of the Chinese nation.

The translation of Evolution and Ethics proved to be the most successful and lasting of Yan's works. Not only did it soon become a must-read for scholars, but also many schoolchildren turned to the book for edification despite its abstruse literary style. ${ }^{15}$ Yan's translation became so influential that reformers such as Liang Qichao cited its ideas extensively in support of the Hundred Days Reform, a comprehensive, though ultimately unsuccessful, reform in late Qing that entailed the establishment of a modern educational system to replace the old. ${ }^{16}$ It also left imprints on scholars of other stripes. Most biologists who studied abroad in the first half of the century had read the book for their secondary education. Although Ma Junwu's translation of Origin was published in 1920, Yan's earlier work still had a wider readership due to its brevity and political relevance.

Ma Junwu also translated Descent later in his life. A prominent educator trained in metallurgy and agricultural chemistry, Ma had served in various posts in the Republican government. He had spent almost two decades finishing a full-length translation of Darwin's On the Origin of Species (1859), which was published in 1920. His translation of Descent, titled Renlei yuanshi ji leize (The Origin of Humankind and Type Selections), was first published by the Commercial Press in 1930, as part of the publisher's collectanea Wanyou Wenku (Complete Library series) containing more than a thousand volumes aimed at making accessible to urban readers a wide variety of works in traditional and modern scholarship. ${ }^{17}$ In this translation, Descent was divided into nine individual volumes, with a semi-vernacular, semi-classical body of text remaining relatively faithful to the original, but with the footnotes omitted, probably to avoid technicality deemed unnecessary for the general public. It was from Ma's translation that the terms xingbie taotai (sexual elimination) and leize (type selection), both used for sexual selection, entered the Chinese lexicon. ${ }^{18}$

The other translation was a self-printed book published in 1934, based on an abridged version edited by Vance Randolph, The Substance of the Descent of Man (1926). ${ }^{19}$ Consisting of about 130 pages, compared to Darwin's original tome of more than seven hundred pages, the abridged version skipped the whole section on sexual selection and highlighted the origin of humans from non-human primates. The translator, Shu Renwen, had studied philosophy and sociology before becoming a businessman in Shanghai. He intended the translation to help dispel lingering beliefs in gods, ghosts and precarious human fates inherited from older generations, by unveiling a natural, non-mystical human origin. Not a biologist himself, shu thought that Ma's semi-classical translation demanded too

15 It is worth noting that the translation was unmistakably non-vernacular and was in a classical, elitist style. The eminent reformer Liang Qichao once commented that 'in his [Yan's] style he is too much concerned with profundity and elegance ... Those who have not read many ancient books found his translations most difficult to comprehend'. Liang Qichao, in Xinmin congbao (1 January 1903) 1, quoted in Schwartz, op. cit. (7), p. 93. Yet some turned to the book exactly to appreciate such a literary style and its translational virtuosity - an emblematic example of the three translational principles Yan championed: 'veracity, readability, and elegance'.

16 Pusey, op. cit. (8).

17 Leo Ou-fan Lee, Shanghai Modern: The Flowering of a New Urban Culture in China, 1930-1945, Cambridge, MA: Harvard University Press, 1999, pp. 55-6.

18 Charles Darwin, Renlei yuanshi ji leize (tr. Junwu Ma), Shanghai: Commercial Press, 1930; Tsing-song Vincent Shen, 'Evolutionism through Chinese eyes: Yan Fu, Ma Junwu and their translations of Darwinian evolutionism', ASIANetwork Exchange (2014) 22(1), pp. 49-60.

19 Darwin and Randolph, op. cit. (4). 
much from non-specialist readers and found Randolph's abridged version more comprehensible than Darwin's original text. ${ }^{20} \mathrm{He}$ aimed at a completely vernacular translation accessible for all literate Chinese and hoped to make the point that in order to understand human society, one needed to start by learning about biology.

The two books fell into relative neglect. For most intellectuals, the turmoil of the Japanese invasion and the Pacific War later in the 1930s made purchases of non-essential books challenging. Among biologists, Descent also failed to find a ready audience. Due to the success of Yan's Evolution and Ethics, when Chinese students began to travel abroad to study biology on a larger scale in the 1910s, they had already perceived the immediate relation between the subject of their study and the survival of the nation. Their general agreement regarding the close connection between animal evolution and human evolution seems to have made it unnecessary for these students to wade through Descent, by then a work from the previous century. When they searched for answers about the future of the Chinese nation through intervening human evolution, newer voices promoting measures of racial hygiene or eugenics were readily available. The content, scope and implication of available publications were heterogeneous, with distinct differences between those in the United States and those in Europe.

Nevertheless, the Republican period (1911-48), especially after the 1920s, was a time when multifarious ideas about the relationship between science, gender and society fomented and became expressed. Before undertaking serious translations or commentaries on Descent in the 1950s, both Pan and Zhu participated in these intellectual discussions before the Communist Revolution. If the previous account explains why Descent interested neither the general public nor experts in the 1930s, the return of an interest in Descent in the 1950s provides a different puzzle. To understand Descent's late ascent and the shape it took, it is crucial to understand the earlier intellectual and social agendas of both scholars.

\section{A eugenic Confucian's dilemma: Pan's path to Descent}

The polymath anthropologist-sociologist Pan Guangdan (潘光旦, 1898-1967, also known as Quentin Pan) was a prolific translator and writer on eugenics, psychology and various social and anthropological topics. Despite his broad interests, he is best known as an influential eugenicist, dubbed the 'father of eugenics in China', a role for which he is still recognized today. By the time he came to translate Descent, sex and its associated cultural and social problems had long fascinated him. In fact, he had read Havelock Ellis's Studies in the Psychology of Sex and Sigmund Freud's psychoanalysis while studying at Tsinghua School between 1913 and 1922, and later published his own translations of Ellis's volumes in $1946 .{ }^{21}$ His first monograph, Feng Xiaoqing, was an exposé that used Freud's notion of sexual repression to reinterpret the life of an early seventeenth-century southern Chinese woman who married a rich man as a second wife and died young. ${ }^{22}$ Despite his clear interest in both sex-related issues and human evolution, he did not translate texts on sexual selection until after his studies of ethnic minorities and decades-long debates with Lamarckians regarding heredity's role in human evolution.

Pan's training in eugenics could not have been more authoritative. Aiming to study biology in the United States after his Tsinghua years, Pan first enrolled in Dartmouth College for the third-year biology class. After obtaining his bachelor's degree in 1924,

20 Darwin and Randolph, op. cit. (4) pp. 2, 10-11.

21 Tsinghua School was then a preparatory school for selected Chinese youth bound to study in the United States upon their graduation, before it became a fully fledged university in 1925.

22 Pan Guangdan, Feng Xiaoqing, Shanghai: Xinyue Bookstore, 1927. 
he enrolled at Columbia University; studied zoology, palaeontology and genetics; and earned a master's degree in 1926. Studies of Mendelian genetics through the fruit fly Drosophila melanogaster were expanding at Columbia and Pan enjoyed the opportunity of working with the prominent geneticist Thomas Hunt Morgan. ${ }^{23}$ However, his true interest was not flies in tubes, but human improvement through biology. Pan eventually attended classes held at the Carnegie Institute in Cold Spring Harbor on eugenics and other related topics such as anthropology, human measurement, endocrinology and cell biology. These training courses were led by the famous Charles Davenport (1866-1944) at the Center for the Study of Eugenics and the Eugenics Record Office. They were designed to prepare workers for researching eugenics with real human populations in the United States and internationally. Their palpable influence on Pan was manifest in the reports he sent back to the Carnegie Institute from China after his return, reporting on his Galtonian research that traced genealogies of talented opera singers and high-ranking intellectual families in the lower Yangzi delta. ${ }^{24}$

Like many eugenic writers, Pan did not usually cite Darwin verbatim, although a social Darwinism was implicit throughout his works. In fact, in 1924, Pan used the last of his savings to purchase the complete works of Darwin before returning to China. Like Davenport, Pan was Galtonian with a firm belief in the importance of heredity in human intellect and other abilities. Recently, scholars have suggested that there was direct influence from Galton's eugenic ideas to Darwin's views about how heredity worked in humans. Diane Paul and James Moore in particular have argued that Galton's publications emboldened Darwin in Descent to assert the hard heredity of a variety of human traits and to emphasize genealogical research in understanding human evolution. ${ }^{25}$ The general sense that morality and emotion have innate heredity as a basis is an underlying premise throughout Descent. ${ }^{26}$ What made Galton's work different from Darwin's was his active promotion of selective coupling of talented individuals for producing desirable traits in future generations. Darwin similarly disapproved of John Stuart Mill for believing that education and environment could shape human nature in powerful ways. Later in his biography Darwin discussed this influence, stating that he was inclined to agree with Francis Galton ... that education and environment produced only a small effect on the mind of any one, and that most of our qualities are innate'. ${ }^{27}$

Racial considerations were connected to almost all eugenic efforts from the outset. Not only had Galton's Hereditary Genius included a chapter analysing the comparative worth of different races, but also eugenics' varied origins and developments outside Britain and the United States tended to vary depending on particular local understandings of race, especially in relation to the local people's self-positioning. The idea of Rassenhygiene (racial hygiene) in Germany, for example, meaning the study of the best conditions for the

23 Three other prominent geneticists, Li Ruqi, Chen Zhen and Lu Huilin, also studied at Morgan's laboratory. For these scientists' work see Laurence Schneider, Biology and Revolution in Twentieth-Century China, Lanham, MD: Rowman \& Littlefield Publishers, 2003; Lijing Jiang, 'Retouching the past with living things: indigenous species, tradition, and biological research in Republican China, 1918-1937', Historical Studies in the Natural Sciences (2016) 46(2), pp. 154-206; Ayo Wahlberg, Good Quality: The Routinization of Sperm Banking in China, Oakland: University of California Press, 2018.

24 See his news published in Pan Guangdan, 'Eugenics and anthropology in China,' Eugenical News (1926) 11(7), p. 104.

25 Diane B. Paul and James Moore, 'The Darwinian context: evolution and inheritance', in Alison Bashford and Philippa Levine (eds.), The Oxford Handbook of the History of Eugenics, Oxford: Oxford University Press, 2010, pp. 27-42.

26 Charles Darwin, The Descent of Man, and Selection in Relation to Sex, 2nd edn, London: John Murray, 1874, pp. 111, 119, 584.

27 Charles R. Darwin and Nora Barlow, The Autobiography of Charles Darwin, 1809-1882: With Original Omissions Restored, New York: Harcourt Brace, 1958, p. 43. 
maintenance and development of a race, shared the same intention as eugenics. The German geneticist Fritz Lenz thus argued in the 1920s that Rassenhygiene was best translated into English simply as eugenics. ${ }^{28}$ Similarly, efforts in social hygiene, marriage education and improvements for women and children's health in Latin America, China and Japan in the first half of the twentieth century were usually attached to an agenda named 'good breeding', which might also be simply translated as eugenics. ${ }^{29}$

To explore ways of maintaining and improving the Chinese race through eugenic means was exactly what Pan had in mind when he returned to China in 1926. He first published a series of articles introducing Davenport's eugenics and Raymond Pearl's human biology. In these publications, in addition to including relatively faithful translations of content in Galtonian eugenics, Pan also reflected upon the potential eugenic values of monogamous family and traditional Chinese conventions and ethics. ${ }^{30}$ The 1920 s was a time when Western conceptions of marriage based on individual will, mutual love and gender equality began to make inroads into Chinese cities. In light of these ideas, scholars, industrialists and students debated the role of patriarchal Chinese family structures in which marriages were usually arranged by parents to keep the family status quo or out of economic convenience. Pan's long interest in sex and gender relations, now coupled with consideration of racial improvement, led him to evaluate the matter quite differently from liberal intellectual elites. In a survey of popular understandings of mate selection and family arrangements, Pan, a translator of Western scholarship himself, was appalled that some of the liberal ideas from Europe were so influential that not only the average age of marriage became delayed among elite youth, but also some of the youth being surveyed also regarded marriage as a social institution that should be abolished altogether within fifty years. ${ }^{31}$ Pan lamented that these well-educated youth would lead China to follow the degenerative path already seen in Europe, where the well-educated population had many fewer offspring than the less-educated population. He emphasized an adage in Confucian tradition - 'Among three deeds that disobey filial piety, to have no offspring is the most unforgivable' - that should be promoted to preserve China's future generations, especially among the elites. ${ }^{32}$

Later in the 1930s, to counteract what he saw as over-westernization of marital and sexual practice, Pan revisited Confucian family ethics to mine its eugenic values. In his two-part article 'Sociobiological implications of Confucianism', published in April 1933, he presented Confucius as a forefather of sociobiological and eugenic thinking and praised Confucian arguments for legitimization of class distinctions, restricted educational access for the lower class, and family influence in orienting individuals to certain predetermined paths for social harmony and family continuity. ${ }^{33}$ As families in Confucian tradition emphasized the duty-bound value of filial piety, they could guarantee a stable environment for intermarriage of individuals of similar social backgrounds, which would in turn enhance the traits most fitting to germlines' social milieus. The religion-like

28 Marius Turda, 'Race, science, and eugenics in the twentieth century', in Bashford and Levine, op. cit. (25), pp. 62-79.

29 Yuehtsen Juliette Chung, Struggle for National Survival: Eugenics in Sino-Japanese Contexts, 1896-1945, New York: Routledge, 2002; Nancy Leys Stepan, 'The Hour of Eugenics': Race, Gender, and Nation in Latin America, Ithaca, NY: Cornell University Press, 1991.

30 These articles were later gathered and published as an anthology in 1928, the first volume in his Human Biology series (Renwen shengwuxue luncong). Guangdan Pan, Yousheng gailun (A General Introduction to Eugenics), Shanghai: Xinyue Bookstore, 1928.

31 Pan Guangdan, Zhongguo jiating zhi wenti (Problems of Family in China), Shanghai: Xinyue Bookstore, 1928.

32 Pan, op. cit. (31).

33 Leon Antonio Rocha, 'Quentin Pan in the China Critic', China Heritage Quarterly (2012) 30-1, at www.chinaheritagequarterly.org/features.php?searchterm=030_rocha.inc\&issue=030. 
veneration of forebears, and respect and service to parents and aged relatives, in addition, highlighted the value of family lineages. Thus, for Pan, Confucius had already set up a great foundation for Galton's and Davenport's eugenics to flourish. To encourage marriage and procreation at a moderately early age, Pan also nodded to the Confucian adage 'It is virtuous for a woman to have few talents', so that women could devote more energy to family and child-rearing.

Prolific as a writer on many issues, Pan's contribution to bona fide eugenics work following Davenport's leadership consisted of two genealogical studies. They were both published in the 1940s. One traced the genealogies of scholarly families in the south of Yangzi river and the other concerned the lineages of talented Chinese opera singers. ${ }^{34}$ For the studies, Pan's training in classical scholarship gave him a ready entry to longitudinal family records.

Not all of Pan's works and writings were consistent with his own Galtonian identity, and he was criticized for both his Galtonian view about a hard heredity of human traits and his various inconsistencies. Although Pan insisted on the importance of heredity in the formation of human traits that seemed to be explained by education or customs like intellectual capability or demeanours - he sometimes retreated to an explanation of 'cultural selection' without explaining how such selection worked in human societies. In addition, Pan did not make a Galtonian prescription for systematic elimination of inferior traits through obliterating the chance for reproduction for certain populations. His suggestion of marital practices that would maintain class structures and stable social milieus did not need a hard heredity to be valid. In fact, the suggestion sounded more like a Lamarckian argument about the importance of social environment. Indeed, one of the criticisms Pan received was from the sociologist Sun Benwen (1892-1979) for 'considering cultural influences as biological determinants'. ${ }^{35}$ In response, Pan re-emphasized his conviction in the role of biological components in what were understood as "cultural influences'. Yet the vague demarcation between what was cultural and what was biological, and how 'cultural selection' worked, continued to haunt Pan's later works, especially when he waded deeper into studies of cultures.

The distinction between natural selection and cultural selection was non-trivial in Pan's own work, as he believed that the Chinese nation was going through a transition from being dominated by natural selection to the cultural selection that characterized a modern society. Again, his thoughts were reflected in his translational work. In the third volume of his Human Biology series, Racial Characteristics and Racial Hygiene, published in 1937, he summarized various Chinese characteristics by translating the writings of American missionary Arthur Henderson Smith, who had speculated about how these traits could be formed in certain natural environments. These characteristics included diligence, frugality, contentment, (too good) patience, lack of accuracy, tranquillity, lack of public pursuit, lack of sympathy, indirect speech and deceptive manners. ${ }^{36}$ Smith suggested that these traits, positive and negative, had been selected because China's large territories and frequent famines and wars required migrations of large numbers of people. In order to ensure group survival, individuals needed to intensively work with peers and governments, and this would often make it necessary to sacrifice individual interest for the benefit of the group.

34 Pan Guangdan, Zhongguo lingren xueyuan zhi yanjiu (An Investigation on the Lineages of Chinese Opera Singers), Shanghai: Commercial Press, 1941; Pan, Mingqing liangdai jiaxing de wangzu (Distinguished Families in Ming and Qing Dynasties), Shanghai: Commercial Press, 1947.

35 Sun Benwen, 'Zailun wenhua yu youshengxue' (Rediscussing culture and eugenics), Shehui xuekan (1929) 2, pp. $1-45,9$.

36 Pan Guangdan, Minzu texing yu minzu weisheng (The Nation's Characteristics and Its Racial Hygiene), Shanghai: Commercial Press, 1937, pp. 15-21. 
Pan also translated extensively from the Yale geographer Ellsworth Huntington's book The Character of Races (1924) for a discussion of the formation of these Chinese characteristics. Although these traits had helped racial preservation in the past, according to Pan, these traits' fitness significantly decreased in the twentieth century, when citizens' public concerns, critical thinking and scientific understanding became essential for China's survival and advancement. ${ }^{37}$ In order to accelerate formations of these traits, which were desirable for a modern society, Pan suggested state interventions be established not only to ensure human welfare but also to encourage stable marriage, procreation and the maintenance of traditional gender values. He prescribed increased famine relief, equality in the distribution of social wealth, contained urbanization (due to the city's effect in reducing procreation), free speech and liberal education, along with eugenic education, in forming such proper families. ${ }^{38}$

Pan's peripatetic style of learning nevertheless led him to other fields in investigating human societies, especially anthropology and sociology. These disciplines perhaps offered a kind of intellectual refuge for Pan in the early years of socialist China, when the government banned genetic research and teaching following the Soviet Union, and at a time when Pan's publications about human heredity and his connections with American academia were heavily criticized. His last monograph on eugenics, the third edition of Principles of Eugenics, was published in 1949, after which he rarely expressed his eugenic ideas any more. ${ }^{39}$ At a time when Communist iron ladies were celebrated as 'holding half of the sky' and when Confucianism and Morgan's genetics were precarious topics to discuss, Pan avoided sensitive topics and delved into historical and anthropological studies of ethnic minorities. In his diaries, he consistently indicated his passive approach to the political learning that was forced on intellectuals, and in August 1949 he noted learning about Lysenko. ${ }^{40}$ Now no longer a professional geneticist, Pan seemed to be minimally affected by Lysenkoism. In 1952, he was appointed at the Minzu University of China (former name Central University of Nationalities) to lead research on Chinese ethnic minorities in the central south. ${ }^{41}$ Before his death in 1967, Pan diverted his attention to studies of ethnic minorities and conducted three substantial historical, sociological and anthropological studies of Chinese minorities or events, including an anthropological study of the Jewish population in the northern province of Henan, a similar study of the Tujia minority, and a sociological analysis of land reform in the Sunan area. He confirmed that the name Tujia ('earthy family') actually derived from the Chinese term for savage (tuzhu, 'earthy tribe'). In the process of observing the population of the Tujia ethnic group, Pan analysed their rituals, supposedly bellicose characteristics, and possible relation to the $b a$ people recorded in historical documents. ${ }^{42}$ This historical identification of Tujia helped to establish Tujia as one independent ethnic minority in official classification, but also became one of the reasons Pan became classified as a rightist in 1957 based on his work that promoted 'division of nationalities'. ${ }^{43}$

In finding connections of historical records of $b a$ and contemporary Tujia, Pan used linguistic tracing of places and tribes, relations with tigers in their environs, and the

37 Pan, op. cit. (36).

38 Pan, op. cit. (36), pp. 212-29.

39 Pan Guangdan, Yousheng yuanli (Principles of Eugenics), Shanghai: Guanchashe, 1949.

40 Pan Guangdan, Pan Guangdan riji (The Diaries of Pan Guangdan), Beijing: Qunyan Press, 2014, p. 115.

41 Lü Wenhao, Pan Guangdan tuzhuan (Illustrated Biography of Pan Guangdan), Wuhan: Hubei People's Press, 2006, p. 193.

42 Pan Guangdan, 'Xiangxi bei de “tujia” yu gudai de ba ren' (The Tujia minority at the northwest of Xiang river and the ba people in antiquity), Zhongguo minzu wenti yanjiu jikan (1955) 4, pp. 1 -135.

43 Lü, op. cit. (41), p. 202. 
worship of a 'white tiger deity' to establish the historical continuity. ${ }^{44}$ Although Pan did not reflect on the formation of these characteristics in relation to sexual preference and practice, he would have been quite interested in such a connection. His new curiosity concerning anthropological studies of Chinese ethnic minorities might have provided an incentive for Pan to translate Descent, in which Darwin's observations of the Fuegians would speak directly to questions that Pan was concerning himself with. ${ }^{45}$

In the new socialist context, foreign publications were less available and were often targets of political suspicion. However, it was on the publishing agenda of the influential Commercial Press in Shanghai to translate a number of influential Western scholarly works, especially those that influenced Marx himself, a plan which the government gave a green light to in 1956. When the editors at Commercial Press started to solicit Western classics in science to translate, Pan immediately recommended Descent. ${ }^{46}$ It happened that Pan's daughter Pan Naisui and her husband Hu Shouwen, both then biologists working at Peking University, could offer additional help in the translation, and they started a collaboration. With some on-and-off work in the 1950s, the project gained momentum in 1962 when the Commercial Press eventually assessed the project and officially commissioned it in the series Chinese Translations of World Scholarly Classics. ${ }^{47}$ The translation was nearly finished in 1966, but due to the impending Cultural Revolution (1966-75) its publication was delayed. ${ }^{48}$ Pan himself was labelled an 'antirevolutionary academic authority' and forced to undertake hard labour. One year later, in 1967, he passed away with a minor illness due to intentional medical neglect from the 'Red Guards'. The manuscript, however, was almost miraculously preserved and seemed to need only partial reworking before its final publication in 1983.

Overall, the text of the translation based on the second edition of Descent published in 1874 was unremarkable. The text was faithful and up to date with the renewed scientific terminology in modern Mandarin Chinese. There was little additional annotation besides some explanation of concepts and historical background. In others' reminiscence about the translation process, the dimension of sex and gender was never mentioned, and probably gingerly avoided. ${ }^{49}$ What was emphasized was the scholarly ingenuity of both Darwin and Pan. Yet one can easily imagine Pan's approval when translating passages like this: 'Both sexes ought to refrain from marriage if they are in any marked degree inferior in body or mind; but such hopes are Utopian and will never be even partially realized until the laws of inheritance are thoroughly known'. ${ }^{50}$ At a time when little could be done with regard to his social intervention about improving the Chinese nation via genetics or eugenics, dwelling on Darwin's text offered an outlet for his social imagination.

Pan's great interest in human evolution was to combine statecraft and the education of the individual to maintain a set of pro-eugenic values, racial or national in nature. He was agnostic regarding the distinction between positive and negative eugenics and focused on developing means for maintaining existing social, political, administrative or familial structures while spreading biological knowledge that he thought useful to the public. Given his conservative stance, it is no surprise that some scholars quoted Pan to support

44 Pan, op. cit. (42).

45 Evelleen Richards, Darwin and the Making of Sexual Selection, Chicago: The University of Chicago Press, 2017, pp. 1-31.

46 Fei Xiaotong, 'Afterword', in Darwin, op. cit. (5), pp. 948-56.

47 Pan, op. cit. (40), pp. 245, 252, 271.

48 Darwin, op. cit. (5).

49 See Fei, op. cit. (46).

50 Charles Darwin, The Descent of Man, and Selection in Relation to Sex, London: John Murray, 1874, pp. 617-18. 
the state's recent policy in subduing political criticism from activists for the sake of 'social harmony..$^{51}$ Descent may have offered a historical cornerstone of such ideas that Pan could assess in those silent years. Interestingly, a social imagination of a highly racialized eugenics that involved women's active participation also emerged in other non-Western contexts. Salama Musa, a pioneer of Egyptian socialism, for example, promoted Darwinism and a eugenic state with a great emphasis on gender liberation and marriage licensure regulation. ${ }^{52}$ At the same time, in the Chinese context, the reconsideration of the Darwinian concept of sexual selection could also involve a very different combination of biological and social understandings, as the career of Zhu Xi shows.

\section{Zhu Xi's embryos and anarchism from Paris to Shanghai, I920-I948}

Although Chinese students trained in America have received some scholarly attention in recent years, those who were trained in Japan and Europe have been less studied. These students often received different curricula and cultural exposures and had different kinds of influence in Chinese academia after their return. In his article 'The Chinese work-study movement in France' published almost three decades ago, Paul Bailey argues that even though this movement ultimately failed, it should nevertheless be seen 'as an important episode in China's educational modernization'. Its promotion of 'the unity of intellectual and manual work' had a surprising parallel with Mao Zedong's later educational thought. ${ }^{53}$ In the field of biology, students trained in Europe in the early twentieth century were influenced by different experimental traditions and philosophical leanings. Zhu Xi (1900-62) was one scientist whose world views and understandings of reproduction had been greatly shaped by diverging developments in France.

Zhu would eventually engage with Darwin's Descent in the late 1950s for discussing human evolution, more than two decades after his return from France. Born in Linhai, Zhejiang Province, Zhu went to France in May 1920 as a participant in the 'work-study programme'. It was said Zhu joined the programme only after being expelled from school because of his participation in the May Fourth Movement and after giving up his fellowship in the previous year to help out another fellow in need. Zhu's work-study years were full of challenges, typical for students who joined the programme. Upon arriving in Paris, Zhu had to live in tents on the lawn in front of the Chinese Federation. He frequently had to change jobs between different factories, and endure difficult physical labour, poor living conditions and harsh discrimination. He attended the University of Montpellier and studied under the French embryologist Jean Eugène Bataillon (1864-1953) from 1925 to 1932. These years of working in factories also gave $\mathrm{Zhu}$ significant time to read broadly about biology at night, which was part of the original purpose of the work-study programme in France and other set-ups for Marxist worker-intellectuals across Europe to work a manual-labour job during the day would free the mind to read and discuss with fellow workers in the evenings. The experience not only provided a broad knowledge base for his later writing in popularizing biological science, but seems also to have shaped his preference for a grass-roots, hands-on and somewhat anarchistic policy on education. He established himself as an expert on parthenogenesis and reproductive biology, publishing popular-science works on reproductive biology and evolution, while inventing techniques for agricultural breeding of fish and silkworms along the way.

$51 \mathrm{Li}$ Yanqiu, 'Pan Guangdan de “weiyu” lun yu goujian hexie shehui' (Pan Guangdan's theory of weiyu and the construction of the socialist harmonious society), Journal of Huangshan University (2007) 9(6), pp. 61-4.

52 Marwa Elshakry, Reading Darwin in Arabic, 1860-1950, Chicago: The University of Chicago Press, 2013, pp. 245-7.

53 Paul Bailey, 'The Chinese work-study movement in France', China Quarterly (1988) 115, pp. 441-61. 
Evolutionary and eugenic thought in France and the collective experience of the workstudy programme significantly shaped how Zhu understood science and its education and popularization. ${ }^{54}$ While in France, a number of students became exposed to anarchism, Kropotkin's theory of mutual aid and the ideal of grass-roots education. Some of these approaches to science, after 1949, were challenged under the Communist state, while others seemed to show great affinity to the state ideology as the Chinese Communist Party advocated 'theories combined with practice' and 'science for the masses'.

Zhu's PhD research in biology was concerned with questions of how eggs and sperms take form in individuals, how fertilization works, and how a fertilized egg develops into a full-blown individual organism. Particularly, the notion that development happened because some inductive agents caused cells to grow and self-organize into more complex structures, initially suggested by the Spemann school of experimental embryology, held sway in the 1920s and 1930s. It led a number of European and American researchers to pay attention to how exactly cells grow, move and divide in the process of forming various parts of animal bodies, such as frog's legs or chicken's wings. ${ }^{55}$ The topic was decidedly not particularly popular in biology even then, as a series of breakthroughs in the studies of Mendelian genetics through the fruit fly Drosophila melanogaster, done by Thomas Hunt Morgan's team at Columbia University, led to productive research projects at the time.

Zhu's adviser, Bataillon, was especially keen on studying embryological development through artificial parthenogenesis - that is, the use of chemical or physical methods to induce the embryonic development of an unfertilized egg. The study of artificial parthenogenesis could be traced to the work of the German American biologist Jacques Loeb in the 1880s. Loeb found that by treating sea urchin eggs with appropriate inorganic salt solutions he could initiate embryological development. This showed that physical chemistry could be a tool for altering the basic process of reproduction. It also showed that it was possible to separate the sperm's function as the initiator of development from its role as the carrier of the male hereditary characters. Loeb believed that it would be possible to manipulate each process independently, and perhaps create hitherto unknown sets of hybrids by superimposing artificial parthenogenesis on eggs fertilized by foreign sperm that were normally unable to initiate development of those eggs. ${ }^{56}$ Loeb's mechanistic view of life, along with his famous experiments on parthenogenesis and an anti-Mendelian stance, may have been known to Zhu as Loeb's work was introduced to a Chinese intellectual readership in $1920 .^{57}$

Developing Loeb's work, by the 1920s, Bataillon had been successful in using both mechanical and chemical methods to induce parthenogenesis. In amphibians, he found that if one injected a white blood cell into an egg, the egg would start to divide and form an individual. When Zhu joined Bataillon's team, the latter had started to use eggs of amphibians, silkworms and sea urchins to induce parthenogenesis. From these results, Zhu and Bataillon theoretically divided fertilization processes into three stages: activation, recovery and final integration of materials. They suggested that the role of the white blood cell was to make possible the recovery of material needed for the final integration of materials. ${ }^{58}$

54 Zhang Zhijie, 'Zhu Xi yu wuzhengfu zhuyi' (Zhu Xi and anarchism), Science \& Culture Review (2008) 5(3), pp. 3, 21-34.

55 Viktor Hamburger, The Heritage of Experimental Embryology: Hans Spemann and the Organizer, Oxford: Oxford University Press, 1988.

56 Philip J. Pauly, Controlling Life: Jacques Loeb and the Engineering Ideal in Biology, Oxford: Oxford University Press, 1987.

57 Wan Guoding, 'Jihui shijie' (The world of chance), Kexue (1920) 5(12), pp. 1263-79.

58 E. Bataillon and Tchou-Su, 'Analyse de la fécondation chez les Batraciens par l'hybridation et la polyspermie physiologique', Archiv für Entwicklungsmechanik der Organismen (1929) 145, pp. 779-824. 
Without explicitly articulating the relationship between the cytoplasmic roles in embryogenesis and development, this research nevertheless turned Zhu's attention to the egg, instead of the sperm, in thinking about both individual developmental processes and potential future change in a society. For the time, the methods Bataillon and Zhu used to induce parthenogenesis were quite sophisticated, such as using carbon dioxide to treat the eggs from the rain frog. They also tried to cross eggs with sperm from different species. Some of the crossed eggs developed to normal adults. Others formed some sort of zygote that developed into tadpoles but died in one to two months. Still others could not form any viable zygotes at all. Zhu's work on parthenogenesis continued after 1949. For example, he started to use distilled water to induce the maturation of the eggs and reached some positive results. He also started to study whether these eggs shared the same physiological functions as normal eggs produced by more natural processes. Eventually, Zhu crafted 'the theory of three essentials' (三元论) of fertilization and concluded that three factors determined the success or failure of fertilization: the maturity level of the egg, the activity level of sperm and the environment for fertilization. In this work, Zhu emphasized the active role of the egg, a point he often referred to in order to emphasize the importance of women in society.

Doing research in the laboratory and publishing in professional journals were only part of the many endeavours Zhu engaged in. After he returned to China, throughout the late 1930s and the 1940s, Zhu published eight monographs in the Modern Biology series. Among these books, six focused on the human biology of sex and reproduction. Their titles included Egg out of Human or Human out of Egg, Women over Men, The Change between Male and Female, and The Source of Love. The second book, Zhongnü qingnan (Women over Men), explicitly referred to pathogenesis to argue for the importance of women in society. All of these books, by telling histories of scientific understanding and recent research in the Western world about how eggs and sperm were generated, and how fertilization, heredity and even parthenogenesis worked, aimed to dispel various superstitious beliefs about reproduction as well as backward notions about the inferiority of women. These goals aligned with the various 'modernizing projects' typical of intellectuals after the New Culture movement who tried to revamp various traditional beliefs with Western science. Zhu's writings were distinguished by their strong leaning toward a specific trajectory of development in French eugenics that had been occurring since the late nineteenth century.

The understanding of eugenics in France was originally quite diverse. The effect of the First World War, however, quickly narrowed down these diverse interests into a single predominant stream, a positive kind of eugenics focused on a neo-Lamarckian improvement of the population through engineering of macro- and micro-environments. The watchword of the French Eugenics Society became 'social hygiene'. ${ }^{59}$ While the war obliterated a significant portion of the working population and exacerbated the problem of a low birth rate, negative eugenic measures such as the elimination of an unwanted population of certain traits or race made little sense to French intellectuals. To improve social conditions through opening sanatoriums and outpatient centres for venereal diseases, and through tighter regulation of alcohol, made more sense to France at the time. By the 1930s, instructions for proper childcare in feeding, bathing and diapering infants had entered the textbooks of both public and Catholic schools. The scientific understanding of heredity and birth was supposed to be foundational for these educational projects. In addition, the selection of proper mates with sound and desirable qualities was also

59 William H. Schneider, Quality and Quantity: The Quest for Biological Regeneration in Twentieth-Century France, Cambridge: Cambridge University Press, 1990, pp. 116-18. 
emphasized as an important factor for ensuring the strength and health of the next generation. $^{60}$

The Lamarckian understanding of evolution, which was still quite popular among scientists and laymen alike in early twentieth-century France, was exactly what had attracted $\mathrm{Zhu} \mathrm{Xi}$ in his early years of work-study. As he mentioned in the preface to his book Biological Evolution (1958), Zhu had learned about 'natural selection' and 'survival of the fittest' since his years in advanced grades of elementary school while in China. Thus, when he started to read French during the work-study years, he often consulted the writings of evolutionists such as Lamarck, Darwin, Haeckel and Huxley, and, in his own words, he almost became 'a disciple of neo-Lamarckism'. ${ }^{61}$ Indeed, Zhu's later works in popular science were infused with eugenic thinking of a French stripe.

In his Philosophie zoologique (1809), Lamarck had postulated two causes of transmutation: an inherently progressive trend that forces living organisms to gradually ascend the chain of being, and the inheritance of acquired characteristics as a mechanism for adapting them to an ever-changing environment. Although popular understanding of 'Lamarckism' at present has been overly focused on the second cause of transmutation, the understanding of what Lamarckism entailed was quite 'mutable' in France before and after the First World War. Although the late nineteenth century had seen a heyday of neo-Lamarckism, after the war most scientists were disenchanted from the hope that experiments could provide direct evidence for the inheritance of acquired characteristics. Outside the ranks of the experimental biologists, however, Lamarckism still held a decisive influence on the public imagination. Some palaeontologists and field naturalists continued to write in reference to Lamarckian evolution, and the philosophical message about environmental influence on generations, such as the notion of psycho-Lamarckism, showed up in popular writings such as those by George Bernard Shaw. The downturn of Lamarckism was nevertheless solidified when the highly advertised experimental results of Paul Kammerer showcasing inheritance of acquired characteristics in midwife toads were exposed as a fraud. ${ }^{62}$

Bataillon indeed had discouraged Zhu's Neo-Lamarckian interest. This was not so much because Bataillon rejected Lamarckian evolution altogether, but because he regarded it as impossible to prove or disprove Lamarckian arguments with experimental science. speciation and formations of larger biological groups such as genera, families and orders, argued Bataillon, usually took place over eons and could not be tackled within the confined timescale of the laboratory. Thus, although Zhu did not do research directly on the problem of evolution, his neo-Lamarckian view was kept intact. In fact, in the late 1930s he started to collect materials for writing about biological evolution with substantial coverage of Lamarckian views. However, as the Communist Party supported Darwinian evolution, Zhu intentionally delayed the publication of Biological Evolution until the 'Hundred Flowers' policy initiated in 1957 encouraged intellectuals to voice views that were different from Party doctrines. ${ }^{63}$

A combination of Lamarckism and eugenics through educational and environmental interventions provided the overall framework in Zhu's Modern Biology series. Lamarckism lent importance to the environment of populations and allowed radical changes in generations to occur. The French-fashioned emphasis on proper knowledge of sex and reproduction for the betterment of a racial future provided the text's

60 Schneider, op. cit. (59), pp. 121-4, 132-3.

$61 \mathrm{Zhu}$ Xi, Shengwu de jinhua (Biological Evolution), Beijing: Science Press, 1958, p. i.

62 Peter J. Bowler, The Eclipse of Darwinism: Anti-Darwinian Evolution Theories in the Decades around 1900, Baltimore: Johns Hopkins University Press, 1983, pp. 75-106.

$63 \mathrm{Zhu}$, op. cit. (61), p. ii. 
organizational and discursive goal. Even though most of these books focused on nonhuman species, Zhu unmistakably intended to highlight the implications of related biological knowledge in human society.

According to the subjects being discussed, Zhu's eight books in the Modern Biology series could be divided into four pairs. The first two books, Human out of Egg and Egg out of Human (蛋生人与人生蛋) and Ancestors of Ours (我们的祖先) deal with the ontogeny (the formation of gametes, fertilization and embryonic development) and phylogeny (evolutionary history) of humans. The second pair, Women over Men (重女轻男) and The Change between Female and Male (䧳雄之变), describe phenomena in sex change and parthenogenesis existing in nature, and how they could be manipulated with experimental methods. In Women over Men, Zhu argued against the preference for sons, an attitude then common among Chinese families. He argued about the prime importance of women in society based on the predominant role of the egg in influencing the fate of the future embryo and on the fact that parthenogenesis - a form of single-female reproduction - existed. However, he did not try to naturalize intersexuality in humans or encourage a cultural sympathy for eunuchs. The third pair, The Source of Intellect (智识 的来源) and The Source of Love (爱情的来源) both had strong eugenic leanings. While the former discusses methods for properly rearing children and how following these methods may lead to the development of superior intellect, the latter explains the psychology of heterosexual romantic love in terms of its value for ensuring reproduction and human survival. The last two books, Vitamins and Human Health (维他命与人类之健康) and Hormones and Human Survival (霍尔蒙与人类之生存) explain how various biomolecules affect human physiology and health. With such a sequence, the last two books seemed to offer 'social-hygiene' measures through an understanding of nutrition and physiology. Applications of these measures were encouraged not only to prevent diseases, but also to improve the physiological environment for the next generation.

These eight books formed a continuum in which Zhu derived messages from principles of reproductive and evolutionary biology as well as their exceptions and particularities to shed light on proper regimes of citizens' life. The major difference between Zhu's subscription for sexual and family practices and Pan's is twofold. First, Zhu rarely asserted a hard heredity for moral or social behaviours, and he did not study the genealogy of humans or animals. His emphasis was on individual lifetimes, not their forebears. $\mathrm{He}$ argued for the improvement of citizens through betterment in education and by improving their natural and social environment. Second, Zhu seldom concerned himself with state interventions. To him, education alone should suffice for cultivating a fully 'eugenic' society.

The writing and publication of the Modern Biology series certainly did not happen in a social vacuum. Zhu's understanding of the history of biology and his interest in popularizing science took shape during the decade in France while he worked in factories by day and read books about biology by night. Among these readings, Zhu admired most the works of Félix Le Dantec, a radical Lamarckian, and thus almost 'became a disciple of neo-Lamarckism' himself. ${ }^{64}$ The publisher for the series, Culture Life Press (文化生活出 版社), was under the directorship of the prominent writer Ba Jin (巴金), who friended $\mathrm{Zhu}$ while they both work-studied in France. In addition, science popularization work was one channel through which $\mathrm{Zhu}$ implemented his anarchist understanding of mass education. As Bailey has insightfully noted, the work-study programme in France accorded with Li Shizeng's belief 'in the unity of intellectual and manual work as the means to bring about mutual assistance, co-operation and equality in

$64 \mathrm{Zhu}$, op. cit. (61), p. i. 
society'. ${ }^{65}$ Zhu himself had a firm belief both in anarchism and in Peter Kropotkin's theory of mutual aid, which proposed a system of economics based on mutual exchanges made in a system of voluntary cooperation. As scholar Zhang Zhijie has pointed out, Zhu had read and translated Kropotkin's Mutual Aid: A Factor of Evolution before 1925, and his close friends, such as Ba Jin and Bi Xiushao, usually had some anarchist leanings, in contrast to others who became attracted to communism instead, such as the famous Zhou Enlai, who became the first prime minister after the Communist Revolution. ${ }^{66}$

Related to his grass-roots, hands-on understanding of education, Zhu also helped to establish local schools near his home town. Using earnings from his first two published books, he started the Linshan School, which combined an elementary school, a middle school and an agricultural school. The school encouraged students to learn knowledge through various hands-on activities. From the fourth grade onward, one hour of agricultural or industrial work was incorporated into the daily curriculum. The lyrics of the school anthem stated, "to work and to study at the same time, to labour with both hands and hearts'. Nevertheless, Zhu did not associate himself with distinctive political camps. Perhaps his emphasis on education, not social revolution, in a way reflected the anarchist spirit as well.

\section{Socialist biology and Descent's late arrival, I95I-1958}

In the wake of the Communist Revolution in China, the study of biology went through a profound change. The sharp downturn of genetics as the Chinese Communist Party reorganized natural sciences following the Soviets is well known. In the USSR, the views of agronomist Trofim Lysenko that species were not fixed but could undergo change under different 'living conditions' became dominant, so that many criticized classic genetics as overly conservative and politically problematic. When the Chinese Communist Party followed suit in redirecting biology, most geneticists in China were no longer able to continue their research or teaching and had to adapt their expertise in other directions. ${ }^{67}$ Although Pan was engaged with studies of eugenics based on hard heredity in the 1920s, his later work was diverse enough to escape a narrow view of a hard heredity. Zhu, likewise, evaded the heredity question by focusing on the question of the dynamics of the embryo. Criticized on various intellectual or political pretexts, neither of them was much affected by the wave against genetics per se.

While geneticists working in this period often simply went dormant and stopped teaching certain subjects, biology in secondary education saw profound changes. Accounts of how species were the result of evolutionary change, and thus kept changing under the right living conditions, became significant in newly published textbooks. In an anthology published in 1951, The Reform of Biological Education in Middle Schools, a number of Soviet educational essays were translated, in addition to original essays contributed by pro-communist philosophers, biologists and teachers within China. As expected, these essays stressed that natural dialectics was the most progressive philosophy and it should guide biological education. ${ }^{68}$ In an essay on 'The reformation of education in biological science', the anatomist Lu Yudao (卢于道, 1906-85) noted that the old views of organisms had been characterized by an isolationist, static tendency that depicted heredity and mutation

65 Bailey, op. cit. (53), p. 445.

66 Zhang, op. cit. (54).

67 Laurence Schneider, 'Michurinist biology in the People's Republic of China, 1948-1956', Journal of the History of Biology (2012) 45, pp. 525-56.

68 New Society for Education, Zhongxue shengwu jiaoxue de gaizao (The Reform of Biological Education in Middle Schools), Beijing: People's Education Press, 1951. 
as separate and mechanical. The new and correct way of viewing them, according to Lu, was to expose the relation between organisms and their living conditions, as well as the relation between individual development and heredity/mutation, as unified through dialectics. He summarized that a philosophically correct opening remark of a biology textbook should not be a statement about the diversity of the living world, as had been often the case in foreign textbooks, because, he argued, to stress diversity gave the false impression that living organisms were separate from each other. Instead, he suggested that textbooks begin with an emphasis on the regularity of the living world, such as “生物学是研究生物发展 规律的科学; 只有掌握了这种发展规律才能改造生物” ('Biology is a scientific subject that studies the regularities of biological development; only after we master these developmental regularities can we change these organisms. $)^{69}$ In this educational context, Zhu started to write Biological Evolution in the early 1950s to create a systematic textbook on the subject. As a long-time Lamarckian, Zhu found a perfect opportunity to review and criticize Darwin's conception of selection and particularly sexual selection. The comprehensive volume first offers a history of evolutionary thought from Chinese antiquity, and from Aristotle to Goethe, Darwin and the idea of transmutation. Zhu then reviewed the 'factual basis for evolution' offered from palaeontology, genetics, biochemistry and biogeography. In a section on theories of evolution, Darwinian ideas occupied merely ten pages, while discussions about Lamarckism, orthogenesis, transmutation and other theories filled the remaining two hundred pages in the section. Zhu, along with almost all Chinese scientists, had no qualms regarding the point that humans had evolved from apes. But he had great concerns about natural selection based on a Malthusian assumption.

Zhu quoted Darwin, translated from the French translation of Descent published in 1872, 'most naturalists will admit that the greater size, strength, courage, and pugnacity of the male, his special weapons of offence, as well as his special means of defence, have been acquired or modified through that form of selection which I have called sexual'. Yet he commented that the female was not passive either, but made the very choices that shaped those male traits, and that Descent was almost a 'romantic novel about animals'." His selected examples include mating songs of Sylvia luscinia L, the mating run of Tetrao phasniellus, and the mating dance of the birds of paradise.

After dutiful summary and some translated excerpts from the French translation (1872) of Darwin's Descent, along with Origin, in the chapter 'Darwin's evolutionary thought', he conducted a point-by-point criticism. ${ }^{71}$ These were not verbatim translations of either work, but summaries of the main points of both works and criticisms of each of them. ${ }^{72}$ Perhaps to highlight his points of criticism, Zhu translated natural selection and sexual selection as 'natural elimination' and 'sexual elimination'.

Regarding sexual selection, Zhu first summarized earlier criticisms voiced by others. First, since the sex ratio of most species is usually kept in good check and balance, close to one to one, it seemed the effect of sexual selection should be minimal. Second, some of the animal species Darwin discussed regarding the evolution of colour patterns and pleasing sounds were actually blunt in their visual or auditory senses. He also criticized the lack of experimental evidence for sexual selection, which Darwin himself confided, and the lack of differentiation among sexes in many animal species. ${ }^{73}$ Then he went into a full attack on the notion of selection based on competition, referring frequently to Kropotkin's theory of mutual aid. Zhu noted that the harsh natural

69 New Society for Education, op. cit. (68), 50.

$70 \mathrm{Zhu}$, op. cit. (61), pp. 51-2

$71 \mathrm{Zhu}$, op. cit. (61), p. i.

$72 \mathrm{Zhu}$, op. cit. (61), pp. 41-62.

$73 \mathrm{Zhu}$, op. cit. (61). 
environment was usually not a good basis for evolution of diverse characteristics. Only when the environment was relatively stable and friendly to species' survival could diverse adaptation generate different characteristics, reaching the species' fullest potential. Zhu did not discuss the implications of his arguments for human society in Biological Evolution. One may speculate that this elision was a strategy to avoid being seen as critical of the Communist government for its failure in offering a satisfactory material and cultural environment for its citizens at the time.

\section{The forgotten Descent and neo-eugenics}

These two engagements with Descent in the 1950s masked two opposing undercurrents of projected roles for women in the Chinese nation through hard heredity (choosing mates selectively and performing reproductive functions) or a softer cultural intervention (education, and women's education in particular). Both directions of thinking originated from attempts to interpret developments in biology happening elsewhere to suit China's circumstances in the 1920s and both reached diametrically positioned confirmative or revolutionary roles for women in society. However, because their biological works came to be largely ignored in the waves of political movements that sidelined most intellectuals in the 1950s, their views were almost completely ignored by the nation at large. As Pan may have had the chance to view Zhu's volume in Beijing, Zhu was probably completely unaware of Pan's ongoing translation in Shanghai.

Interestingly, Zhu's idea of women's role in society in the Republican era may have entered the communist consciousness via a twist regarding women's contribution to the nation's labour force. In the 1950s, the image of the 'iron woman', often presented in posters as a female character holding a sickle prepared to contribute to the nation's agricultural yield, had a dominant place in the state media. Women were also encouraged to contribute to the population of socialist workers by giving birth to as many children as possible, thus becoming a 'hero mother'. Yet their choice of mates and educational contribution were not emphasized unless they could be linked to a socialist zeal. Pan and Zhu's earlier ideas about women's role in Chinese society were not only lost in their works dealing strictly with academic biology in socialist China, but also overwhelmed by the ideological emphasis on women's productivity in the dire material conditions of the new republic.

New waves of publications about eugenics, on the other hand, arrived soon after the economic reforms of the late 1970s. Not being associated with a past history of genocide, the Chinese equivalent term for eugenics, yousheng ('good birth'), came to be used as an umbrella term for mate selection and foetal learning. Numerous manuals and anthologies were compiled and consumed, often rehashing ideas voiced in the first half of the century. Both the proper choice of mate based on social status and the proper rearing and education of the next generation were intensively discussed, primarily targeting women of reproductive age as readers. The implementation of the one-child policy (1979-2015) further motivated prospective parents to take heed of the full range of advice handed out. In the flourishing market that started to consume these ideas, and that seemed to have synthesized what Pan and Zhu expressed in the 1930s, the distinctions between hard and soft heredity, the social milieus in which the prior generations had formed these ideas, and the relation of these ideas to Darwin's book, became ever more obfuscated. Perhaps this was rather a sign of success on the part of Pan and Zhu as translators or scientists: their interpretations about mate selection and women's education were assimilated to the intellectual and cultural substrates so well that few people could tell they had once been divergent local readaptations of late nineteenth-century biological thoughts. 
Acknowledgements. I thank Erika Milam and Suman Seth for the wonderful opportunity to develop this intellectual exploration along with other more established scholars on the general topic in this volume. They, along with two anonymous reviewers, have offered most valuable suggestions to improve the paper, even if restraints of source and time cannot allow more adequate response to all of them. I also appreciate helpful editorial suggestions from the chief editor of this journal, Simon Werrett.

Cite this article: Jiang L (2021). The late ascent of Darwin's Descent: exploring human evolution and women's role for a new China, 1927-1965. BJHS Themes 6, 201-220. https://doi.org/10.1017/bjt.2021.11 